\title{
Effect of Practical Work on Grade 10 Learners' Performance in Science in Mankweng Circuit, South Africa
}

\author{
Israel Kibirige \\ Maake M. Rebecca \\ Francis Mavhunga \\ Department of Mathematics Science and Technology Education, University of Limpopo \\ Email: Israel.Kibirige@ul.ac.za
}

Doi:10.5901/mjss.2014.v5n23p1568

\begin{abstract}
The effect of practical work on learners' performance in Science was investigated using a quasi-experimental design with preand post-tests. 60 learners $(N=30)$ for the Experimental Group were taught using practical work while $(N=30)$ for the Control Group were taught without practical work. Results from post post-tests show that learners from the EG outperformed those from the $C G$. Average mean of $E G(M=22.8, S D=6.50)$ and average mean of $C G(M=11.3, S D 3.0)$ were statistically different (t-test $=8.63, d f=58, p<0.05$ ) and ANCOVA results suggest that the difference was due to the effect of practical work. A Mann-Whitney U-test show that there was no significant differences in performance between boys and girls in the $E G$. Findings from this study show that practical work improved learners' performance. The implication for teachers is that the use of practical work in teaching of Physical Sciences improves learners' performance.
\end{abstract}

Keywords: Practical work, integrated processes, chalk-and-talk, learners' performance, learners' experience

\section{Introduction}

Practical work is necessary for school science education. In Science, learners do practical work to expand their knowledge in an attempt to understand the world around them (Kolucki \& Lemish, 2011). It develops learners' understanding of ideas, theories and models (Millar \& Abrahams, 2008). Thus, teaching science involves learners experiencing the basic and integrated processes of science (NARST, 1990; Millar et al. 1999). Research has established that achievement and skills improved when students are taught science using practical work (Kerr, 1963; Turpin \& Cage, 2004; Aladejana \& Aderibigbe, 2007; Watts, 2013). However, as observed, practical work is not done in some schools in the country due to inadequate resources, lack of practical science skills and large classes in science (pers. Obs) and (Onwu \& Stoffel, 2005; Ramnarain, 2014).

To ensure equal treatment in different schools, curricula prescribe the levels and the amount of practical work as well as subsequent assessments. The Curriculum Assessment Policy Statement (CAPS) guides teachers on what content to teach, describes the number of practical sessions and the complexity of practical work for Grades 10-12 in South African schools (CAPS, 2012). Surprisingly, teachers' attitudes towards practical work is poor, consequently they do it to satisfy the minimum requirements of the syllabus (Kibirige \& Teffo, 2014). In addition, a study was conducted with a random sample of 266 Grade 10 students from across South African schools to test the general quality of practical skills, and the results show that learners' argumentations were of low quality (Lubben, Sadeck, Scholtz \& Braund, 2010).

While practical work is assumed to be necessary for all learners, some studies show that boys and girls differ in the reception of the practical approach (Gardner, 1975; Anderson, Sjoberg \& Mikalsen, 2006; Trumper, 2006). Learners benefit through engagement with concepts in practical work through "interactions, hands-on activities, and application in science" (Hampden-Thompson \& Bennett 2013: 1340). Without withstanding such benefits, Gardner (1975) shows that sex may determine pupils' attitudes towards science. This is further confirmed by research in Ghana (Anderson, Sjoberg \& Mikalsen, 2006), England (Jenkins, 2006), Israel (Trumper, 2006) and Finland (Lavonen, Byman, Uitto, Juuti, Meisalo, 2008) where boys and girls of the same age tend to have different attitudes to similar teaching styles. On the other hand, a study by Kibirige and Tsamago (2013) shows that the attitudes of boys and girls towards science are not different when using similar methods. Thus, due to differing views, this study will also analyse if there is gender differences in performance when learners are taught using practical work. 
Several studies point to learners' persistent lack of experimentation skills, inadequate resources and prevalence of large classes and it can be inferred that there is no effective change in such classrooms (Onwu \& Stoffels (2005); Luben et.al (2010); Ramanrain (2014). Consequently, learners' performance is poor in science subjects (Mji \& Magkato, 2006). This type of performance ultimately results in negative attitude towards practical work and science. In order to improve learners' attitudes (Kibirige \& Tsamago, 2013) and understanding of science, practical work could be used (Kibirige, Osodo \& Tlala et al., 2014). Thus, practical work should be an integral part of teaching and as such this study aimed at establishing the effect of practical work on the learners' performance. In order to achieve this aim the following questions guided the study: 1) Do learners doing practical work perform better than those learning science without practical work; and 2) Do boys and girls doing practical work differ significantly in their average scores when they learn using practical work?

\section{Literature}

Practical work is defined as "...learning experiences in which students interact with materials or with secondary sources of data to observe and understand the natural world." (Lunetta, Hoffstein \& Clough, 2007 p.393). Practical work in literature has been referred to in different ways: 'experimental work; scientific investigations (Ramnarain, (2011); 'practical and investigative activities' (SCORE 2008), and 'laboratory investigations' (Kibirige \& Tsomago, 2013). The broad perspective of 'learning experiences' will be understood to include the wide range of practical skills, thought and processes that constitute doing science as 'what scientists do' (Benner, 2011).

Some authors in science education contend that practical work in science has many purposes (Woodley, 2009; Hodson, 1990; Vilaythong, 2011). For instance Watts $(2013$, p.4) lists some of these purposes required by the General Certificate of Education as:

"motivation for students -the excitement of discovery, consolidation of theory, development of manipulative skills, knowledge of standard techniques, general understanding of data handling, development of other skills (e.g. analytic, evaluative, planning, applied, mathematical) and understanding of how science works: concepts of scientific process, collaborative working, reproducible results, fair testing."

Another purpose for practical work is the understanding of errors and how to design practical procedures in order to improve precision and accuracy. Students acquire skills for safety; risk and precaution against hazards in the laboratory (SCORE, 2008). Practical work also provides learners with evidence to support their understanding and to concretise scientific principles (Jormanainen, 2006). Thus, learners are exposed to basic processes of science through practical work.

Practical work has traditionally been a 'recipe-like' activity that had minimal cognitive engagement and did not inspire originality in students (Bigelow, 2012). Research by The National Research Council ([NRC], 2003) and (National Academy of Sciences ([NAS], 2010) have recommended that during practical work learners should be investigative, design their own experiments, record and analyse as well as find their own answers. Driver (1983) suggested that instead of learners dealing with already known answers, such as determining known constants, they need to investigate novel problems. In this way practical work supports development of scientific skills, thinking skills and how scientists work. However, other researchers found that the inquiry approach in practical work requires much time and a session of one hour is never enough (Abraham \& Millar, 2008). Practical work caters for learning in different ways such as experiential, independent, team and peer dialogue (Zimbardi, Bugarcic, Colthorpe, Good \& Lluka, 2013). Different learning styles have the pedagogic benefit of enabling correct concept development. They underscore the empirical nature of science, measurement, repeatability of experiment and learners may enquire as real scientists do. While these pedagogic benefits have yielded encouraging results in science classrooms elsewhere, this has not been the case in South Africa (Buthelezi, 2012, Mji \& Makgato 2006). Onwu \& Stoffels (2005: 79) using mixed methods research with 53 practicing teachers in Venda, Limpopo established that most teachers had 'little experience, meagre training, and operated in large and poorly resourced science classrooms". Consequently teachers resort to chalk-and-talk, lecturing and demonstrations when teaching Physical Sciences.

Many weaknesses are inherent in the South African science teacher education enterprise. Bradley and Smith (1994) reported that teachers themselves emerged from an education system that did not groom them to do experiments or practical work. The lecturers in pre-service training lacked the knowledge and experiences in conducting practical work. Schools were also found to lack equipment and laboratories (Onwu \& Stoffels, 2005) as well as laboratory technicians to support teachers. Muwanga-Zake (2008) further established that even headmasters kept science 
equipment for display in their offices and were never used in the science classrooms! This further confirms that principals lack understanding of the purpose of practical work and its role in the CAPS science curriculum. One of the major requirements of CAPS is that teachers should do at least one practical in physics per term, for the purpose of formal assessment (CAPS, 2012). The combined effect of the poor resources in schools and the CAPS requirement results in an observable lack of practical work in science classes.

Literature is awash with the observation that practical work produces good performance in science (Kerr, 1963; Muwanga-Zake, 2008; Watts, 2009). Despite such observations, Kahle (1999, p2) noted that "Schools are only as good as their teachers, regardless of how high their standards, how up-to-date their technology, or how innovative their programs". Similarly, low level content, lack of practical skills and negative attitudes towards innovative science teaching are the problems besetting teachers and consequently teachers do not use practical work in their science classes (Onwu \& Stoffels, 2005; Lubben et. al., 2010; Kibirige \& Tsomago, 2013).

\section{Problem Statement}

Despite the effectiveness of practical work, teachers in some South African schools are not confident to teach science using practical work (Kibirige \& Tsamago, 2013). Consequently, such teachers rely on traditional ways of teaching: lecturing, chalk-and-talk and dictation. These traditional strategies seem to be favoured because either there are no laboratories for learners to perform practical work (Kibirige \& Tsamago, 2013) or it is because teachers lack skills, even if schools have laboratories (Muwanga-Zake, 2008). Worse still, teachers who use practical work normally depend on textbooks and teach experiments like cookbook recipes. Such teaching strategies often fail to inculcate conceptual understanding in learners. Therefore, this study aimed at establishing how practical work in science can enhance learners' conceptual understanding in order to improve performance.

\section{Methodology}

\subsection{Research design}

A quasi-experimental design was used to measure the effect of practical work on high school learners' understanding of science (Campbell \& Stanley, 1963). Two groups were designated experimental group (EG) and control group (CG) and both groups were pre-tested to determine the level of science content understanding. EG was taught the topic of Heat and Temperature for three weeks, using practical work while the CG was taught the same topic using the traditional methods with no practical work.

\subsection{Sample of Research}

The study sample 60 learners of Physical Science learners from two Grade 10 classes in Mankweng Township was purposively selected because that school was due to teach Heat as a content topic during the period of the study. Two whole classes were used. Class A was the CG ( $N=30: 17$ girls and 13 boys) and was taught using traditional methods (lecturing and no practical work). Class $B(N=30: 16$ girls and 14 boys) was the $E G$ and taught the topic 'Heat and Temperature' for three weeks using practical work.

\subsection{Instruments}

Teacher-designed activities were used as pre- and post-tests for both EG and CG. The designed pre- and post-tests were presented to lecturers from the local university for content validation. Neighbouring high school science teachers were also consulted to check the suitability of the two sets of tools. For reliability, the pre- and post-tests were piloted on 10 Grade 10 learners. Cronbach alpha obtained was 0.960 suggesting that these tools were suitable to be used in the study.

\subsection{Data collection}

Data was collected over a three week period, through pre and post-tests. Both the EG and the CG were pre-tested to determine levels of science understanding. This was done to ensure homogeneity of the two groups. During 3 weeks both groups were taught these topics: Activities 1-2 were on States of Matter, Activity 3 was on Heat Transfer, Activities $4-5$ 
were on Heat vs. Temperature Calorimetry and activity 6 was on Soda and Celsius: An experiment on Heat and Temperature using carbonation, and Activity 7 was on the heating and cooling curves of water. In the EG these topics were presented as practical work where learners handled the apparatus, performed experiments and recorded data, and drew conclusions. On the other hand, the CG was taught using lecture method and in addition notes were given to learners. After 3 weeks of teaching the same post-test was administered to both groups.

\subsection{Data Analysis}

A t-test was used to measure the difference in performance of learners in pre-test and post-test for both EG and CG. A Mann-Whitney U-test was used to test for any differences between the performance of boys and girls in the EG. Analysis of co-variance (ANCOVA) was used to determine the differences due to the treatment. The pre-test scores were used as a covariate to control for initial group differences, reduce the error variance and eliminate systemic bias (Dimitrov \& Rumril, 2003). Effect sizes were calculated using Cohen's $d$ (Cohen, 1988).

\section{Results}

Table 1 shows the pre- and post-test differences in performance of learners in EG and CG.

Table 1: Pre-test and post - test overall mean difference $p<0.05$

\begin{tabular}{lcccccc}
\hline & $\mathbf{n}$ & $\mathbf{M}$ & $\mathbf{S D}$ & $\mathbf{t}$ & $\mathbf{P}$ & $\mathbf{d}$ \\
\hline EG & & & & & & \\
Pre- test & 30 & 8.70 & 2.40 & -11.03 & 0.00 & 0.90 \\
Post - test & 30 & 22.80 & 6.50 & & & \\
CG & & & & & & \\
Pre - test & 30 & 7.30 & 3.50 & -4.72 & 0.21 & 0.60 \\
Post - test & 30 & 11.40 & 3.00 & & & \\
\hline
\end{tabular}

Data in Table 1 reports outcomes of a paired samples $t$-test for the overall mean scores for the EG group and the CG. The mean $(M=22.8, S D=6.5)$ for post-test of $E G$ was statistically different from the pre-test mean $(M=8.70, S D 2.40)$ and t-test -11.03; $p<0.05$. On the other hand there was no statistical difference between the CG post-test $(M=11.40$, $S D=3.0)$ and the pre-test $(M=7.30, S D=3.50)$ and t-test $-4.72 ; p>0.5$. The effect size in the EG was $(d=0.92)$, while CG effect size was $(d=0.65)$.

\subsection{Do the EG scores differ significantly from those of the CG in pre- and post-test?}

Table 2 shows the pre-test results per question for the EG and CG.

Table 2: Pre-test results per question $p<0.05$.

\begin{tabular}{cccccccc}
\hline Type of test & Question & Treatment & $\mathrm{M}$ & $\mathrm{SD}$ & $\mathrm{t}$ & $\mathrm{p}$ & $\mathrm{d}$ \\
\hline Pre test & 1.1 & $\mathrm{EG}$ & 5.50 & 1.57 & 1.47 & 0.01 & 0.16 \\
& & CG & 4.87 & 2.23 & & & \\
& 1.2 .1 & EG & 0.00 & 0.00 & -2.11 & 0.00 & 0.27 \\
& 1.2 .2 & CG & 0.27 & 0.68 & & & \\
& EG & 0.97 & 0.98 & 0.65 & 0.89 & 0.09 \\
& 1.3 .1 & EG & 0.80 & 0.98 & & & \\
& & CG & 0.17 & 0.52 & -0.24 & 0.68 & 0.03 \\
& 1.3 .2 & EG & 0.50 & 0.54 & & & \\
& & CG & 0.27 & 0.68 & 1.16 & 0.03 & 0.15 \\
& 2.1 & EG & 0.60 & 0.92 & -0.80 & 0.13 & 0.11 \\
& 2.2 .1 & CG & 0.80 & 0.98 & & & \\
& & EG & 0.43 & 1.20 & 1.24 & 0.02 & 0.16 \\
& 2.3 .1 & CG & 0.13 & 0.50 & & & \\
& & EG & 0.20 & 0.60 & 0.00 & 1.00 & 0.00 \\
\hline
\end{tabular}




\begin{tabular}{llllllll}
\hline 2.4 .1 & EG & 0.13 & 0.50 & 0.00 & 1.00 & 0.00 \\
& CG & 0.13 & 0.50 & & & \\
2.5 .1 & EG & 0.00 & 0.00 & & & \\
& CG & 0.00 & 0.00 & & & \\
3.1 .1 & EG & 0.13 & 0.43 & 4.06 & 0.00 & 0.15 \\
& CG & 0.03 & 0.18 & & & \\
& 3.1 .2 & EG & 0.00 & 0.00 & 2.85 & 0.00 & \\
& CG & 0.00 & 0.00 & & & \\
\hline
\end{tabular}

In Table 2 the pre-test values of the EG and CG show 7 items (58\%) suggesting that the overall performance between the two groups is not significantly different. However, the EG post-test in Table 3 show that 9 items $(75 \%)$ had $p$ values ( $p$ $<0.05)$. In addition, the effect size ranged from 0.13 to 0.4 .

Table 3: Post test results of the EG and the CG after teaching.

\begin{tabular}{|c|c|c|c|c|c|c|c|}
\hline Type of test & Question & Treatment & M & SD & $t$ & $p$ & $d$ \\
\hline \multirow[t]{24}{*}{ Post test } & 1.1 & $E G$ & 6.00 & 0.00 & 1.28 & 0.01 & 0.17 \\
\hline & & CG & 5.73 & 1.12 & & & \\
\hline & 1.2 .1 & EG & 1.47 & 0.88 & 5.28 & 0.06 & 0.45 \\
\hline & & CG & 0.33 & 0.75 & & & \\
\hline & 1.2 .2 & EG & 1.53 & 0.85 & 1.39 & 0.01 & 0.18 \\
\hline & & CG & 1.20 & 0.98 & & & \\
\hline & 1.3.1 & EG & 1.40 & 0.92 & 5.35 & 0.00 & 0.57 \\
\hline & & CG & 0.27 & 0.68 & & & \\
\hline & 1.3.2 & EG & 1.03 & 0.98 & 1.74 & 0.10 & 0.22 \\
\hline & & CG & 0.60 & 0.92 & & & \\
\hline & 2.1 & EG & 0.87 & 0.99 & -1.03 & 1.00 & 0.13 \\
\hline & & CG & 1.13 & 0.99 & & & \\
\hline & 2.2.1 & EG & 3.77 & 2.60 & 6.48 & 0.00 & 0.65 \\
\hline & & CG & 0.33 & 1.16 & & & \\
\hline & 2.3.1 & EG & 1.00 & 1.00 & 1.46 & 0.02 & 0.19 \\
\hline & & CG & 0.63 & 0.91 & & & \\
\hline & 2.4.1 & EG & 0.93 & 1.00 & 3.39 & 0.00 & 0.41 \\
\hline & & CG & 0.20 & 0.60 & & & \\
\hline & 2.5 .1 & EG & 0.47 & 0.81 & 3.12 & 0.00 & 0.38 \\
\hline & & CG & 0.00 & 0.00 & & & \\
\hline & 3.1 .1 & EG & 3.77 & 2.42 & 2.91 & 0.00 & 0.68 \\
\hline & & CG & 0.43 & 0.72 & & & \\
\hline & 3.1 .2 & EG & 0.70 & 0.90 & 3.91 & 0.00 & 0.46 \\
\hline & & CG & 0.03 & 0.18 & & & \\
\hline
\end{tabular}

Average mean of $E G(M=22.8, S D=6.50)$ and average mean of $C G(M=11.3, S D 3.0)$ were statistically different (tTest $=8.63 ; \mathrm{df}=58 ; p<0.05)$. Analysis of co-variance (ANCOVA) shows that the difference was indeed due to the treatment (Post-test $F(1,85.10), p<0.05$; and pre-test as covariate, $F(1,33.10), p<0.05)$ Table 4. The pre-test scores were used as a covariate to control for continuous initial group differences, reduce the error variance and eliminate systemic bias (Dimitrov \& Rumril, 2003).

Table 4: Analysis of covariance (ANCOVA) results for EG post-test with pre-test as a covaiate $(p<0.05)$.

\begin{tabular}{ccccc}
\hline Source & df & Mean Square & $F$ & $p$ \\
\hline pre test & 1 & 560.52 & 33.10 & 0.00 \\
post test & 1 & 1441.17 & 85.10 & 0.00 \\
\hline
\end{tabular}

5.2 Do boys and girls in the experimental group differ significantly in regard to their average performance after practical work?

A Mann-Whitney U-test was conducted to see if there are differences in the post test of boys and girls in the EG and the 
results show that there was no significant differences between boys and girls (Mann-Whitney U-test: $p>0.05$ ) (Table 5).

Table 5: Mann-Whitney U-test between boys and girls in the EG

\begin{tabular}{|c|c|c|c|c|c|}
\hline Type of test & Question & Gender & U & $\mathbf{Z}$ & $P$ \\
\hline \multirow[t]{12}{*}{ Pre test } & 1.1 & $\begin{array}{l}\text { Boys } \\
\text { Girls }\end{array}$ & 106.50 & -0.44 & 0.66 \\
\hline & 1.2 .1 & $\begin{array}{l}\text { Boys } \\
\text { Girls }\end{array}$ & 112.00 & 0.00 & 1.00 \\
\hline & 1.2 .2 & $\begin{array}{l}\text { Boys } \\
\text { Girls }\end{array}$ & 93.00 & -0.90 & 0.37 \\
\hline & 1.3 .1 & $\begin{array}{l}\text { Boys } \\
\text { Girls }\end{array}$ & 105.00 & -0.56 & 0.58 \\
\hline & 1.3 .2 & $\begin{array}{l}\text { Boys } \\
\text { Girls }\end{array}$ & 0.50 & -1.73 & 0.08 \\
\hline & 2.1 & $\begin{array}{l}\text { Boys } \\
\text { Girls }\end{array}$ & 109.00 & -0.16 & 0.88 \\
\hline & 2.2 .1 & $\begin{array}{l}\text { Boys } \\
\text { Girls }\end{array}$ & 1.00 & -0.58 & 0.56 \\
\hline & 2.3 .1 & $\begin{array}{l}\text { Boys } \\
\text { Girls }\end{array}$ & 88.00 & -1.92 & 0.06 \\
\hline & 2.4 .1 & $\begin{array}{l}\text { Boys } \\
\text { Girls }\end{array}$ & 96.00 & -1.54 & 0.12 \\
\hline & 2.5 .1 & $\begin{array}{l}\text { Boys } \\
\text { Girls }\end{array}$ & 112.00 & 0.00 & 1.00 \\
\hline & 3.1 .1 & $\begin{array}{l}\text { Boys } \\
\text { Girls }\end{array}$ & 0.00 & -1.41 & 0.16 \\
\hline & 3.1 .2 & $\begin{array}{l}\text { Boys } \\
\text { Girls }\end{array}$ & 112.00 & 0.00 & 1.00 \\
\hline \multirow[t]{12}{*}{ Post test } & 1.1 & $\begin{array}{l}\text { Boys } \\
\text { Girls }\end{array}$ & 112.00 & 0.00 & 1.00 \\
\hline & 1.2.1 & $\begin{array}{l}\text { Boys } \\
\text { Girls }\end{array}$ & 108.00 & -0.22 & 0.83 \\
\hline & 1.2.2 & $\begin{array}{l}\text { Boys } \\
\text { Girls }\end{array}$ & 93.00 & -1.08 & 0.28 \\
\hline & 1.3 .1 & $\begin{array}{l}\text { Boys } \\
\text { Girls }\end{array}$ & 79.00 & -1.73 & 0.84 \\
\hline & 1.3 .2 & $\begin{array}{l}\text { Boys } \\
\text { Girls }\end{array}$ & 100.00 & -0.57 & 0.57 \\
\hline & 2.1 & $\begin{array}{l}\text { Boys } \\
\text { Girls }\end{array}$ & 68.00 & -2.13 & 0.03 \\
\hline & 2.2 .1 & $\begin{array}{l}\text { Boys } \\
\text { Girls }\end{array}$ & 98.50 & -0.62 & 0.54 \\
\hline & 2.3 .1 & $\begin{array}{l}\text { Boys } \\
\text { Girls }\end{array}$ & 97.00 & -0.72 & 0.47 \\
\hline & 2.4 .1 & $\begin{array}{l}\text { Boys } \\
\text { Girls }\end{array}$ & 90.00 & -1.06 & 0.29 \\
\hline & 2.5 .1 & $\begin{array}{l}\text { Boys } \\
\text { Girls }\end{array}$ & 104.00 & -430.00 & 0.67 \\
\hline & 3.1 .1 & $\begin{array}{l}\text { Boys } \\
\text { Girls }\end{array}$ & 81.00 & -1.33 & 0.18 \\
\hline & 3.1 .2 & $\begin{array}{l}\text { Boys } \\
\text { Girls }\end{array}$ & 92.50 & -0.93 & 0.35 \\
\hline
\end{tabular}

\section{Discussion}

The aim of the research was to establish the effect of practical work on learners' performance in science. Results show that practical work has a significantly positive effect on learners' performance (Table 3). The ANCOVA results show that the difference was indeed due to the treatment and not by other variables. Also, the use of practical work in science 
classes is not gender biased because performance of boys and girls in EG did not differ significantly (Table 5). This is not surprising because both genders are endowed with equal opportunities to succeed in science subjects (Bussey \& Bandura 1999). The high mean of the EG compared to the low CG suggests that students in the former understood science concepts and performed better than those taught without practical work. These results corroborate the studies by Abrahams \& Millar (2008), Aladejana \& Aderibigbe (2007), and Kibirige \& Tsamago (2013) who found similar effects. It has been previously reported that practical work potentially improves learners' performance (Buthelezi 2012; Mji \& Makgato, 2006). Furthermore, Cerini, Murray, \& Reiss, 2003 found that learners were positively motivated by practical work. Cohen $d$ measures of 0.65 and 0.92 (Table 1) suggest that there is a medium to very strong relationship between teaching science using practical work and learners performance (Valentine and Cooper, 2003).

Despite encouraging results, teachers use different types of practical work in science classes (Lunetta \& Tamir, 1979; Millar, Le Maréchal \& Tiberghien, 1999). Different types of practical work achieve different purposes. There is practical work to achieve basic skills like: measuring, observation and recording, while investigative skills include experimental design, analysis of data and drawing inferences. These types of practical work are at times 'ill-conceived, confused and unproductive' (Hodson, 1990: 33). There are reports that teachers often miss-match types of practical work and purpose (Lunetta \& Tamir, 1979; Millar et al. 1999). This suggests that practical work intended to develop one objective cannot improve performance in all other areas of cognition.

While some studies (NAS, 2010; Abrahams, 2009) have recommended that practical work should develop problem solving skills, experimental design and analysis of data, other fundamental skills should precede these high order skills. Kibirige \& Teffo (2014) have shown that basic skills such as measurement, recording and setting up equipment precede higher order objectives such as experimental design and inference. Therefore, the effectiveness of practical work does not lie in just any practical work, but in judicious selection of activities aimed at specific objectives. Practical work to teach learners how to follow simple instructions (the so called cook-book experiments) have their positive pedagogical role such as to train in accuracy and precision. Thus, high order skills may develop after the achievement of fundamental skills.

The selection of the types of practical work requires that teachers know what practical work to do first and which ones to follow. It also suggests that teachers should have a tacit knowledge of how to do practical work by themselves. Tacit knowledge is hard to verbalize because it is expressed through action-based skills and cannot be reduced to rules and recipes and it is the implicit knowledge used by people to do their work and to make sense of their worlds (LaFemina, 2002). The tacit skills involved in practical work therefore cannot be transferred to learners through chalk-and-talk method, but by hands-on activities. Thus, the observation by Onwu and Stoffels (2005) that teachers in Limpopo deliberately avoided practical work may have resulted from inadequate experience in practical work at pre-service teacher training. This suggests that pre-service and in-service teacher training institutions should inculcate practical skills, confidence and positive attitudes towards practical work when training future physical science teachers.

A few studies show that some teachers in South African schools did not use practical work to teach physical sciences (Rumnarain, 2011; Hatting \& Rogan, 2007). This failure may be due to a number of inherent factors. These include: some teachers teaching subjects in which they are not specialised (Mokotedi, 2013); lack of laboratories and equipment; lack of laboratory technicians; and large classes. In the case of specialisation, a teacher who may have trained in Biology, because of teacher shortage may end up teaching Physical Sciences. Such non-specialist teachers are known to be reluctant to do practical work and this is in agreement with (SCORE, 2008; Soares \& Lock, 2007; Abrahams \& Millar, 2008). Large classes and lack of resources are further conditions inhibiting the use of practical work when teaching Physical Sciences (Muwanga-Zake, 2008, Onwu \& Stoffels, 2005). While literature on school laboratory technicians in South Africa is scarce, there is a general lack of laboratories and laboratory technicians to support teachers with practical work. When teachers do the work of technicians, there is chance that teachers end up missing the teaching of relevant content at the desired depth. Muwanga-Zake (2008) observed that many rural schools in South Africa do not have laboratories and it is reasonable to conclude that such schools also did not have technicians. Helliar \& Harrison (2011) explored the role of laboratory technicians (laboratory assistants) in promoting practical work in schools in the UK. Laboratory technicians manage laboratories, equipment stock, the setting up of equipment and they ensure the proper and safe use of equipment. More importantly, technicians support teachers, even those teachers who may not be adept with the practical work. With training and experience, technicians become repositories of practical skills. Thus, less experienced teachers can effectively benefit from such technicians. Unfortunately, sometimes high school graduates are hired to work as untrained laboratory technicians from the same practical-work-starved or deficient school system and hence cannot effectively function as laboratory technicians. As a result technicians are underrated and unacknowledged, underpaid and do not have stable career prospects (Smithers \& Robinson (2005).

The second major result in this study was that there were no differences in the performance of girls and boys in the EG (Mann Whitney-U test, $p<0.05)$ (Table 5). This suggests that both boys and girls performed equally well when taught 
Physical Science using practical work. This finding corroborates the studies by Schreiner and Sjoberg (2004) and Mavhunga (2012) that boys and girls did not differ in cognitive issues but they differ in affective interests. Boys were found to be more interested in technical, hands-on activities and careers while girls were less interested in hands-on activities preferring caring and aesthetic activities.

Conversely, girls in a girls-only school have been found to do better in practical work than boys in boys-only schools (Trivedi \& Sharma, 2013). This could be due to the fact that girls have been found to develop manual dexterity earlier than boys (Junaid \& Fellowes, 2006, Venetsanou \& Kambas, 2011; Tomassini et al., 2011) which could explain that girls do practical work more carefully than boys. Other research shows that there is no relationship between manual dexterity and cognitive growth under 16 years (Takser, Dellatolas, Bowler, Laplante, Huel, 2002). In the end, it can be concluded that practical work is really not gender dependent but can be enhanced by sufficient equipment, practice, confident and knowledgeable teachers and a good attitude towards sciences.

The post-test was administered after three weeks of treatment to the EG group of learners. These previously had no apparatus manipulative skills and had not performed sufficient practical work and hence they needed first to be acclimatized with the method and manipulation skills of equipment. In such circumstances, practical work is often poor and at best haphazardly organised. If practical work were to be consistently planned by both the laboratory technicians and teachers, then the performance of learners would improve (Watts, 2013). This action would redress the poor national performance in science subjects as lamented by Mji and Magkato (2006).

While it is important to encourage practical work, it is equally prudent to consider reducing the number of learners in the science classes (Onwu \& Stoffels, 2005; Muwanga-Zake, 2008). This could be done by separating large classes into many small classes. This action will need more science teachers to be employed and should be addressed by the Department of Education employing more teachers. Deliberate world-wide hiring of graduate teachers from the English speaking world could be done for a period of ten years to man all the deficient schools while South Africa develops her own national pool of teachers. This approach is not new in Africa because in the 1980's Zimbabwe and Botswana used this model to jump-start education (Appleton, Sives \& Morgan, 2006).

Whilst the outcome from this study may be plausible, there was a limitation of external validity due to the EG and the CG of learners sharing information since they attended the same school (Dimitrov and Rumril, 2003). Nevertheless judging from the very high Cohen $d$ value attained, it is reasonable to conclude that such a threat did not have a significant effect on the final results. Also, for ethical issues, learners in the CG were later taught using practical work approach so that they could get the same exposure.

\section{Recommendations}

The findings confirm that the use of practical work is an effective method in improving the performance of school science learners regardless of their gender. Thus, it is recommended that more practical work should be used when teaching Physical Science in South African schools. This requires that teachers of science undergo intensive in-service training in practical work management. The Education Departments need to seek and support those teachers with limited laboratory skills and encourage those who already have sufficient skills and experience to use practical work in science teaching. Pre-service training of teachers should have significant practice in basic and higher order thinking skills so that new teachers are more confident to use practical work when they teach Physical Sciences. Also, teacher training centres should train teachers to use hand-tools so they can improvise, where possible, science equipment for practical work. This may give teachers confidence to set up low-cost practical work in places where there is limited equipment. Finally, all schools offering Physical Sciences should have laboratories and trained laboratory technicians to support the teachers.

\section{References}

Abrahams, I., \& Millar, R. (2008). Does Practical Work Really Work? A study of the effectiveness of practical work as a teaching and learning method in school science. International Journal of Science Education, 30(14): 1945-1969.

Aladejana, F. \& Aderibigbe O. (2007). Science Laboratory Environment and Academic Performance Journal of Science Education and Technology, 16 (6): 500-506.

Anderson, I., Sjøberg, S. \& Mikalsen, Ø. (2006). What kinds of science and technology do pupils in Ghanaian junior secondary schools want to learn about? Some results and comparisons based on the international ROSE study. In C. Julie and Mikalsen, Ø. (Eds.) Some Developments in Research in Science and Mathematics Education in Sub-Saharan Africa Cape Town: University of the Western Cape.

Appleton,A., Sives, A. \& Morgan, W.J. (2006) The impact of international teacher migration on schooling in developing countries-the case of Southern Africa Globalisation, Societies and Education, 4(1):121-142.

Benner, S. (2011). What Scientists do The BIOLOGOS From http://biologus.org Accessed 26 May 2014.

Beyer, B .K. (1991). Teaching thinking skills: A handbook for elementary school teachers. Boston, MA: Allyn and Bacon. 
Bigelow, M. (2012). From cookbook to inquiry http://nstacommunities. org/blog /2012/06/24/from-cookbook-to-inquiry. Accessed May 272014.

Bradley, J.D. \& Smith, C. (1994). Pre-service teacher education and high school practical work In M.J. Glencross (Ed.), Proceedings of the Second Annual Meeting of the Southern African Association of Research in Mathematics and Science Education, University KwaZuluNatal.

Bussey, K., \& Bandura, A. (1999). Social cognitive theory of gender development and differentiation. Psychological Review, 106, 676-713.

Buthelezi, N. (03 August 2012). Inside efforts to turn the tide on South Africa's poor maths and science performance. Creamer Media's Engineering News http://www. engineeringnews.co.zal Accessed 23 February 2014.

Campbell, D.T., \& Stanley, J.C. (1963). Experimental and quasi-experimental designs for research on teaching Houghton: Mifflin Company Boston.

Cerini, B., Murray, I., \& Reiss, M. (2003). Student review of the science curriculum. Major findings. London: Planet Science/Institute of Education University of London/Science Museum. http://www.planet-science.com/sciteach/review Accessed May 30, 2014.

Cohen J. (1988). Statistical power and analysis for behavioural sciences (2nd Ed) Hillsdale New Jersey: Lawrence Erlbaum Associates.

Curriculum Assessment Policy Statement (2012). Department of Basic Education Government of South Africa.

Dillon, J. (2008). A Review of the Research on Practical Work in School Science. King's College London.

Dimitrov, D. \& Rumril, P. D. (2003). Pre-test - post-test designs and measurement of change IOS Press, 20:159 - 165.

Driver, R. (1983). The pupil as a Scientist. Milton Keynes: Open University.

Erdmann, M., Fischer, R., Glaser, C., Klingebiel, D., Krause, R., Kuempel, D., Muller, G., Rieger, Steggemann, M.J., Urban, M., Walz, D., Weidenhaupt, K., Winchen,T., \& Weltermann, B. (2014). A field study of data analysis exercises in a bachelor physics course using the internet platform VISPA. European Journal of Physics, 35 (2014):1-14.

Gardner, P.L. (1975). Attitudes to science. Studies in Science Education, 2(1): p 1-41.

Hampden-Thompson, G. \& Bennet, J. (2013) Science Teaching and Learning Activities And Students' Engagement in Science. International Journal of Science Education, 35(8):1325-1343.

Hattingh, A. \& Rogan, J. (2007) Some factors influencing the quality of practical work in science classrooms. African Journal of Research in SMT Education, 11(1): 75-90.

Helliar, A.T. \& Harrison, T.G. (2011). The role of school technicians in promoting science through practical work. Acta Didactica Napocensia, 4(23): 2011.

Hodson, D. (1990). A critical look at practical work in school science. School Science Review, 70 (256): 33-40.

Hodson, D. (1991). Practical work in science: Time for a reappraisal. Studies in Science Education, 19: 175-184.

Institute of Physics, (2013). Provision for practical science in schools is seriously lacking. The Royal Chemistry Society. From http.www.rsc.org Accessed 4 May 2014.

Jenkins, E.W. (2006). Student opinion in England about science and technology. Research in Science and Technology Education, 24(1): 59-68.

Jormanainen, I. (2006). Challenges on Concretisation of Empirical Modelling: a preliminary analysis Department of Computer Science University of Joensuu, Finland.

Joseph A.D. (2009). How to select, calculate, and interpret effect sizes. Journal of Paediatric Psychology, 34(9): 917-928.

Junaid, K.A., \& Fellowes, S. (2006). Gender differences in the attainment of motor skills on the Movement Assessment Battery for Children Physical and Occupational. Therapy in Paediatrics, 26(1-2):5-11.

Kahle, J.B. (1999). Teacher Professional Development. Do it make a difference in student learning? Testimony To The US House of Representatives Committee On Science - Washington, DC: From http://gos.sbc.edu/k/kahle.html Accessed 3 June 2014.

Kerr, J.F. (1963). Practical work in school science Leicester: Leicester University Press.

Kibirige, I. \& Teffo W.L. (2014). Actual and Ideal Assessment Practices in South African Natural Sciences Classrooms. International Journal of Educational Science, 6(3): 509-519.

Kibirige, I., \& Tsamago, H. (2013). Learners' Performance in Physical Sciences Using Laboratory Investigations. International Journal of Educational Sciences, 5(4): 425-432.

Kibirige, I., Osodo, J. \& Tlala, K.M. (2014). The effect of Predict-Observe- Explain Sttrategy on Learners' Misconceptions about Dissolved Salts. Mediterranean Journal of Social Sciences, 5(4):300-310.

Kim, M. \& Chin, C. (2011, January). Pre-service teachers' views on practical work with enquiry orientation in textbook-oriented science classrooms. International Journal of Environmental \& Science Education, 6(1): 23-37.

Kolucki, B. \& Lemish, D. (2011). Communicating with Children Principles and Practices to Nurture, Inspire, Excite, Educate and Heal. UNICEF. From http://www.unicef.org/ cbsc/files/ CwC_Web.pdf Accessed 23 May 2014.

LaFemina, D. (2002). How Do We Know What We Know? Tacit Knowledge Defined. From: https://academicjobsonline.org/ajo/jobs/3924 Accessed 26 May 2014.

Lavonen, J., Gedrovics, J., Byman, R., Meisalo, V., Juuti, K. \& Uitto, A. (2008). Students' motivational orientations and career choice in science and technology: A survey in Finland and Latvia. Journal of Baltic Science Education, 7(2): 86-103.

Lubben, F., Sadeck, M., Scholtz, Z \& Braund, M. (2010). Gauging Students' Untutored Ability in Argumentation about Experimental Data: A South African case study. International Journal of Science Education, 32(16): 2143-2166.

Lunetta, V.N., Hofstein, A. \& Clough, M.P. (2007). Teaching and learning in the school science laboratory. An analysis of research, theory, and practice In Handbook of research on science education (ed. S K Abell and N G Lederman), pp. 393-431 Mahwah, NJ: Lawrence Erlbaum Associates.

Lunetta, V.N., \& Tamir, P. (1979). Matching lab activities with teaching goals. The Science Teacher, 46(5):22-24.

Mavhunga, F.Z. (2012). Relevance of science education: the voice of Zimbabwe school learners. Lambert: Academic Publishing, Germany.

Millar, R. (2004). The role of practical work in teaching and learning of sciences National Academy of Sciences, Washington DC.

Millar, R., \& Abrahams, I. (2008). Practical work: making it more effective. Retrieved from http://www.gettingpractical.org.uk/documents/ RobinSSR.pdf Accessed 29 May 2014.

Millar, R., Le Marechal, J.F., \& Tiberghien, A. (1999). 'Mapping' the domain. In J. P. Leach \& A.C. Paulsen (Eds.), Practical work in science education (pp. 33-59) Dordrecht, The Netherland: Kluwer Academic Publishers. 
Mji, A., \& Makgato, M. (2006). Factors associated with high school learners' poor performance: a spotlight on mathematics and physical science. South African Journal of Education, 26(2):253-266.

Mokotedi, R.T. (2013).Beginning Primary School Teachers' Perspectives on the Role of Subject Specialization in Botswana Colleges of Education: Implications for the Professional Development of those who did not Specialize in Languages (English and Setswana). International Journal of Scientific Research in Education 6(1):88-99.

Morgan, G.A., Gliner J.A., \& Harmon R.J. (2006). Understanding and evaluating research in applied and clinical settings. London: Lawrence Erlbaum Associates.

Muijs, D. (2010). Doing Quantitative Research in Education with SPSS. Sage Publications.

Musasia, A.M., Abacha, O.A, \& Biyoyo, M.E. (2012). Effect of Practical Work in Physics on Girls' Performance, Attitude change and Skills acquisition in the form two-form three Secondary Schools' transition in Kenya. International Journal of Humanities and Social Science, 2 (23): 151-166.

Muwanga-Zake, J.W.F. (2008). Is Science Education in a Crisis? Some of the Problems in South Africa. Science in Africa. www.scienceinafrica.co.za / scicrisis.htm Accessed: 28 May 2014.

NARST, (1990). Research Matters - to the Science Teacher Retrieved from www.narst.org/ publications/research/skill.cfm Accessed: May 27, 2014.

National Academy of Sciences (2010). A new biology for the 21st century: Ensuring the United States leads the coming biology revolution. Washington, DC: National Academies Press. From http:// www.nap.edu Accessed: 29 May 2014.

National Research Council (2000). Inquiry and the national science education standards: A guide for teaching and learning. Washington, DC: National Academies Press.

Oleson, A. \& Hora, T.M. (2012). Teaching the Way They Were Taught? Revisiting the Sources of Teaching Knowledge and the Role of Prior Experience in Shaping Faculty Teaching Practices Wisconsin Centre for Education. Research Working Paper No. 2012-09.

Onwu, G. \& Stoffel, N. (2005) Instructional functions in large, under-resourced science classes: Perspectives of South African teachers. Perspectives in Education, 23(3): 65-75.

Piaget, J. (1954). The construction of reality in a child. New York: Basis Books.

Ramnarain, U. (2010). Teaching scientific investigations. Northlands, SA, Macmillan.

Ramnarain, U. (2011). Teachers' use of questioning in supporting learners doing science investigations. South African Journal of Education, 31(1):91-101.

Ramnarain, U. (2014). Teachers' perceptions of inquiry-based learning in urban, suburban, township and rural high schools: The contextspecificity of science curriculum implementation in South Africa. Teaching and Teacher Education, 38: 65-75.

Schreiner, C. \& Sjøberg, S. (2004). Sowing the seeds of ROSE. Background, Rationale, Questionnaire Development and Data Collection for ROSE (The Relevance of Science Education) - a comparative study of students' views of science and science education. Acta Didactica, (4/2004).

Science Community Representing Education, (2008). SCORE Report: Practical work in Science: a Report and Proposal for a Strategic Framework, London.

Sellgren, K. (2013). Warning over lack of science practical lessons. http://www.bbc.com/news/education-25015393 Accessed: 2 June 2014.

Shadish, W. \& Clark, M. (2004) Solomon Four Group design. In Lewish-Beck Bryman, and T Liao (Eds), Encyclopedia of Social Science Research methods (pp1048-1049) Thousand Oakes, CA: SAGE Publications.

Smithers, A. \& Robinson, P. (2005). Physics in schools and colleges: teacher deployment and student outcomes. Buckingham, UK: Carmichael Press, University of Buckingham.

Soares, A. \& Lock, R. (2007). Pre-Service Science Teachers' Perceptions of Written Lesson Appraisals: The Impact of Styles of Mentoring. European Journal of Teacher Education, 30(1): 75-90.

Takser, L., Dellatolas, G., Bowler, R., Laplante, N., \& Huel, G., (2002). Predictive factors of manual dexterity and cognitive performance at 17 years: a 10-year longitudinal study in a rural area of France. Percept Motor Skills, 95(1):15-26.

Thompson, F. \& Logue, S. (2006). An exploration of common student misconceptions in science. International Education Journal, 7(4): 553-559.

Tomassini, V., Jbabdi, S., Kincses, Z.T., Bosnell, R., Douaud, G., Pozzilli, C., Matthews, P.M., \& Johansen-Berg, H. (2011). Structural and functional bases for individual differences in motor learning. Human Brain Mapping, 32: 494-508.

Trivedi R. \& Sharma, M.P. (2013). A Study of Students' Attitude towards Physics Practical at Senior Secondary Level. International Journal of Scientific and Research Publications, 3(8): 1-4.

Trumper, R. (2006). Factors Affecting Junior High School Students' Interest in Biology. Science Education International, 17(1): $31-48$.

Turpin, T. \& Cage, B.N. (2004). The effects of an integrated, activity-based science curriculum on student achievement, science process skills, and science attitudes. Electronic Journal of Literacy through Science, 3:1-17.

Valentine, J.C. \& Cooper, H. (2003) Effect size substantive interpretation guidelines: issues in the interpretation of effect sizes. Washington, DC: What Works Clearinghouse.

Venetsanou, F., \& Kambas, A. (2011). The effects of age and gender on balance skills in preschool children. Physical Education \& Sport, 9: 8190.

Vilaythong, T. (2011). The Role of Practical Work in Physics Education in Lao PDR. Doctoral Thesis Department of Physics SE-901 87. Umeå University of Sweden.

Watts, A. (2013). The assessment of practical science: a literature review. Cambridge Assessment.

Wenning, C. J. (2004). Contrasting Cookbook with Inquiry-Oriented Labs Physics Teacher Education Program. Illinois State University.

Woodley, E. (2009) Practical work in school science - why is it important? School Science Review, 91(335): 49-51.

Zimbardi, K., Bugarcic, A., Colthorpe, K., Good, J.P. \& Lluka, L.J (2013). A set of vertically integrated inquiry-based practical curricula that develop scientific thinking skills for large cohorts of undergraduate students. Advances in Physiology Education, 37(4):303-315. 